\title{
Improving Quality Properties of Frozen Yogurt by Fortification with Lemongrass (Cymbopogon citratus) as Prebiotic
}

\author{
Gehad Sallah Saeed Eldeeb $^{1 *}$, Mohamed Abouelnaga ${ }^{2}$ and Sameh Hassan Mosilhey ${ }^{3}$ \\ ${ }^{1}$ Department of Food Technology, Faculty of Agriculture, Suez Canal University, Ismailia, Egypt, 41522 \\ ${ }^{2}$ Department of Dairy, Faculty of Agriculture, Suez Canal University, Ismailia, Egypt, 41522 \\ ${ }^{3}$ Department of Food, Dairy Sciences and Technology, Faculty of Environmental Agricultural Sciences, Arish \\ University, North Sinai, Egypt
}

Received: $15 / 1 / 2021$

\begin{abstract}
The present study was carried out to evaluate lemongrass's antimicrobial activities and probiotic cultures' viability in frozen yogurt. The yogurt was prepared with two different commercial starters of probiotics [Lactobacillus acidophilus (LA-5), Bifidobacterium lactis (BB-12)], incorporation with Streptococcus thermophiles and two various concentrations of lemongrass powder or extract $(0.5 \%$ and $1 \%)$. The data showed that lemongrass extract inhibited all microorganisms' growth at a concentration of $36 \mu 1 / \mathrm{mL}$ for fungi species (Aspergillus niger, Aspergillus flavus and Penicillium spp.) and $48 \mu \mathrm{l} / \mathrm{mL}$ for bacteria species (Pseudomonas fluorescens, aeruginosa, fragi and Aeromonas hydrophila, caviae, sobria). Lemongrass powder or extract produced an alternative, stable color and stable quality of yogurt during frozen storage. Sensory evaluation of frozen yogurt with lemongrass powder $0.5 \%$ had acceptable quality characteristics with higher antioxidant effect (Thiobarbituric acid values 1.02 mg malonaldehyde $/ \mathrm{kg}$ ) after 30 days of frozen storage. The viability loss during frozen storage of commercial probiotic cultures Lactobacillus acidophilus (LA-5) and Bifidobacterium lactis (BB-12) decreased between 0.7, 1.15 and 0.76, $1.36 \log \mathrm{CFU} / \mathrm{g}$, respectively in all treatments. The population of these microorganisms remained above $10^{5} \mathrm{CFU} / \mathrm{g}$.
\end{abstract}

Keywords: Lemongrass; probiotic bacteria; frozen yogurt; fungi; antimicrobial activity; Cymbopogon citrates

\section{INTRODUCTION}

Nowadays, there is an exponential growth in herbal functional foods as consumers everywhere desire diets healthier. Lemongrass (Cymbopogon citratus) is a grass that belongs to Cymbopogon genus and Graminaceae family (Adeneye and Agbaje, 2007). Lemongrass has phytochemicals such as flavonoids, tannins, alkaloids and essential oils. The prefix lemon attributes to its lemon-like typical odor due to the presence of citral, and citral is a combination of two steroisomeric monoterpene aldehydes (Majewska et al., 2019). The aqueous lemongrass extract is commonly used as an aromatic drink and the whole plant is well incorporated into many various traditional foods for its lemon flavor (Figueirinha et al., 2008).

The lemongrass usage was repeatedly found in ancient and recent folk remedies for treating coughs, elephantiasis, consumption, pneumonia, ophthalmia, malaria and vascular disorders. Many researchers have investigated that lemongrass holds antioxidants, antidepressant, astringent, antiseptic, bactericidal, fungicidal, sedative and nervine properties, hypoglycemic and hypolipidemic effects. Further, several studies had proved the lemongrass antibacterial activity against a diverse range of microorganisms comprising both gram-positive and gram-negative bacteria, fungus and yeasts. Lemongrass leaves extract exhibited a tremendous antimicrobial effect against various antibiotics resistant microorganisms ( $\mathrm{Li}$ et al., 2018; De Silva et al., 2017).

Frozen yogurt has characteristics of both yogurt and ice cream and could be used as a probiotics carrier. Culture viability is often facing high stress during frozen yogurt production (Magarinos et al., 2007). The main challenge of probiotic frozen yogurt processing is to ensure the maintenance of the surviving viability during the freezing process and frozen storage below $0^{\circ} \mathrm{C}$ (Favaro-Trindade et al., 2006), especially the lethal effects of ice crystals on probiotics. The benefits of probiotics are well known that they help improve the consumer's general health and prevent many types of diseases and enhance the immune system when consumed sufficiently. These beneficial effects on the consumer can only be achieved by consuming 100 grams daily, containing $10^{5}-10^{6} \mathrm{CFU} / \mathrm{mL}$ or gram (Jayamanne and Adams, 2006). Furthermore, probiotics can develop and improve different types of flavors and the nutritional quality of the product.

Hence the present study was carried out to investigate the potential application of lemongrass powder or extract as a food preservative for its antibacterial activity against some selected spoiling and pathogenic microorganisms and as a source of protection (prebiotic) for probiotic bacteria as well. The herbal ice cream was formulated with probiotics and lemongrass powder or extract based on the acceptable optimal levels and was evaluated according to sensory attributes as response variables.

\section{MATERIALS AND METHODS}

\section{Microbial strains and media}

Aspergillus niger (Asp. niger), Aspergillus flavus (Asp. flavus) and Penicillium spp. were obtained from mycotoxin laboratory, National Research Center, Doki, Cairo, Egypt. Pseudomonas spp. (Ps. fluorescens, aeruginosa, fragi) and Aeromonas spp. (Aero. hydrophila, caviae, sobria) were obtained from the Department of Food Hygiene, Animal Health Research Institute, Cairo, Egypt.

Freeze-dried starters of Lactobacillus acidophilus (LA- 
5) (Lb. acidophilus), Bifidobacterium lactis (BB-12) (B. lactis) and Streptococcus thermophilus (FD-DVS ABT-2- Probio-Tec) (Str. thermophilus) were obtained from Chr. Hansen's Lab, Copenhagen, Denmark. The cultures were stored at $-18^{\circ} \mathrm{C}$ until used before their expiry date. MRS NNLP agar and MRS agar were obtained from Merck (Darmstadt, Germany). Lemongrass leaves (Cymbopogon citratus) were purchased from a local market in Ismailia, Egypt. Leaves were washed with tap water and dried using a connective dryer (WT-blinder, Type F115, Germany) at $40^{\circ} \mathrm{C}$ for 3 days. Dried leaves were finely ground using a blender (Warning Commercial, HGB2WTS3, Torrington, Connecticut, USA).

\section{Preparation of lemongrass powder and extract:}

$300 \mathrm{~mL}$ of boiling water were added to $50 \mathrm{~g}$ of lemongrass powder in a conical flask $(500 \mathrm{~mL})$ and stirred by a magnetic bar on a hot plate for $10 \mathrm{mins}$ at $90^{\circ} \mathrm{C}$. The extract was then filtered and concentrated using rotary evaporator to semi-solid form. The concentrate was stored at $4^{\circ} \mathrm{C}$ until being analyzed.

\section{Minimum inhibitory concentration (MIC) \\ Preparation of extract}

$0.1 \mathrm{~g}$ of extract was dissolved in $100 \mathrm{~mL}$ distilled water $(\mathrm{w} / \mathrm{v})$ to make $100 \mathrm{mg} / 100 \mathrm{~mL}(1000$ $\mu \mathrm{g} / \mathrm{mL}$ ). $5 \mathrm{~mL}$ of the above solution were diluted with $50 \mathrm{~mL}$ distilled water $(\mathrm{v} / \mathrm{v})$ from which desired concentration such as $6,12,18,24,30,36,42$ and 48 $\mu \mathrm{g} / \mathrm{mL}$.

\section{Dilution susceptibility test}

The dilution susceptibility test method was used to determine the minimum inhibitory concentration of leaves extract according to methods described by Brothers and Wyatt (2000) as follows: one $\mathrm{mL}$ of $24 \mathrm{hr}$ activated cultures were serially diluted and one $\mathrm{mL}$ from each dilution (in duplicates) was transferred into petri dishes. Different concentrations of the extract from 0 to $48 \mu \mathrm{g} / \mathrm{mL}$ were thoroughly mixed with 10 $\mathrm{mL}$ sterilized medium (sabouraud dextrose agar for fungi and nutrient agar for bacteria), then poured into the aforementioned petri dishes. The dishes were incubated at $30^{\circ} \mathrm{C}$ and $37^{\circ} \mathrm{C}$ for fungi and bacteria, respectively, for $48 \mathrm{hr}$. Viable colonies were counted, and inhibition percent was calculated and referred to as the viable count at $0.0 \%$ of the extract.

\section{Antimicrobial Assay of leaves extract:}

The crook borer diffusion method was used to measure the antimicrobial activity according to the method described by (Piddock, 1990) by removing a slug from solidified agar media (sabouraud dextrose agar for fungi) with a sterile crook borer $(1 \mathrm{~cm}$ diameter) after inoculation with bacteria or fungi. Leaves extract was added at a concentration of $26 \mu 1$ in duplicates. Inoculated plates were incubated at $37^{\circ} \mathrm{C}$ for bacteria and $28^{\circ} \mathrm{C}$ for fungi, and then inhibition zones (mm) of the microbial growth were measured.

\section{Preparation of Frozen Yogurt}

Frozen yogurt has been prepared, as described by Marshall and Arbuckle (1996). Control of frozen yogurt and four mix formulations were used in this study with different lemongrass levels to represent the effect of lemongrass on frozen yogurt quality and the viability of probiotics. The control of frozen yogurt (T1) was standardized (4\% fat, 11\% SNF, 15\% sugar and $0.25 \% \mathrm{CMC}$ ), while other four-lemongrass frozen yogurt treatments were prepared with adding $0.5 \%, 1 \%$ and $0.5 \%, 1 \%$ lemongrass powder and extract, respectively.

Each frozen yogurt treatment was prepared in three replicates and analyzed for chemical, bacteriological and organoleptic characteristics at zero time and after 7,15 and 30 days of frozen storage at $-18 \pm 1^{\circ} \mathrm{C}$.

The frozen yogurt was prepared as following; skimmed milk powder was reconstituted in warm water to $11 \%$ total solids for yogurt production. The prepared yogurt pasteurized at $85^{\circ} \mathrm{C}$ for $10 \mathrm{~min}$, cooled to $45^{\circ} \mathrm{C}$, and then inoculated with $2 \%$ of freeze-dried DVS starter (Lb. acidophilus (LA-5), B. lactis (BB-12) and Str. thermophilus $) \quad\left(10^{7}-10^{8} \quad \mathrm{CFU} / \mathrm{mL}\right) . \quad$ The inoculated yogurt incubated at $45^{\circ} \mathrm{C}$ for $4 \mathrm{hrs}$ (to final $\mathrm{pH}$ 4.8).

\section{Viability of probiotics}

The viability of probiotics was determined before freezing [zero time] (neglected results), postfreezing, 7, 15 and after 30 days of storage period by serial dilutions in sterilized peptone water by pour plate method. Lb. acidophilus (LA-5) was enumerated by using MRS agar while $B$. lactis (BB-12) was determined by MRS NNLP agar. All these plates were incubated at $37^{\circ} \mathrm{C}$ anaerobically for $72 \mathrm{hrs}$.

\section{Chemical analysis}

The chemical composition of samples for ash, crude fiber, fat, moisture and protein contents were determined according to the method of AOAC (2012). Carbohydrates were determined by difference (Table, $1)$.

Table (1): Chemical composition (\%dry matter) of lemongrass leaves (Mean $\pm \mathrm{SD}$ )

\begin{tabular}{lcccccc}
\hline $\begin{array}{c}\text { Proximal } \\
\text { analysis }\end{array}$ & $\begin{array}{c}\text { Moisture } \\
\text { content }\end{array}$ & $\begin{array}{c}\text { Crude } \\
\text { protein }\end{array}$ & Total ash & fat & fiber & Carbohydrate \\
\hline Wet weight & $66.09 \pm 0.121$ & $3.50 \pm 0.008$ & $2.80 \pm 0.314$ & $3.37 \pm 0.32$ & $8.34 \pm 0.516$ & $15.90 \pm 0.021$ \\
& & & & & & \\
Dry weight & - & $10.32 \pm 0.143$ & $8.26 \pm 0.002$ & $9.94 \pm 0.171$ & $24.59 \pm 0.221$ & $46.88 \pm 0.085$ \\
\hline
\end{tabular}




\section{Thiobarbituric acid value (TBA)}

Lipid oxidation was measured by the 2thiobarbituric acid distillation method of Pearson (1981); $10 \mathrm{~g}$ yogurt sample was macerated with $50 \mathrm{~mL}$ water for 2 mins and washed into a distillation flask with $47.5 \mathrm{~mL}$ water. After that, $2.5 \mathrm{~mL}$ of $4 \mathrm{M} \mathrm{HCl}$ were added to bring the $\mathrm{pH}$ to 1.5 , followed by any antifoaming preparation and a few glass beads. The flask was heated utilizing an electric mantle so that 50 $\mathrm{mL}$ distillate is collected in 10 mins from the time boiling commences. $5 \mathrm{~mL}$ of the distillate was pipetted into a glass-stoppered tube, and then $5 \mathrm{~mL}$ TBA reagent $(0.2883 \mathrm{~g} / 100 \mathrm{~mL}$ of $90 \%$ glacial acetic acid $)$ were added, stoppered, shook and heated in boiling water for 35 mins. A blank was prepared similarly using $5 \mathrm{~mL}$ water with $5 \mathrm{~mL}$ reagent. The tubes was cooled in water for 10 mins and the absorbance (D) versus blank was measured at $538 \mathrm{~nm}$ using a spectrophotometer (T80 UV/VIS, PG Instruments Ltd, UK).

TBA No. [as mg malondialdehyde (MDA) $/ \mathrm{kg}$ sample]= $7.8 \mathrm{D}$

\section{Sensory evaluation}

Sensory properties of frozen yogurt control and all treatments were evaluated in the same day of processing (day, 1) and after 7, 15 and 30 days of storage at $-18 \pm 1^{\circ} \mathrm{C}$ according to the method of Salama (2004). Flavor (45 points), body and color (10 points) and total score (100 points) were evaluated by 15 panelists of the experienced staff members of Food Technology and Dairy Departments, Faculty of Agriculture, Suez Canal University, Egypt.

\section{Instrumental color measurement}

Objective measurement of color (CIE $L^{*}, a^{*}$ and $b^{*}$ ) was performed at the surface of yogurt samples using a color reader CR-10 (Konica Minolta sensing, Inc., Osaka, Japan). In this coordinate system, the $L^{*}$ value is a measurement of lightness, ranging from 0 (black) to 100 (white), $a^{*}$ value ranges from -100 (greenness) to +100 (redness) and $b^{*}$ value ranges from -100 (blueness) to +100 (yellowness). The redness index $\left(a * / b^{*}\right)$ was determined as described by Chen et al. (1997).

\section{Statistical analysis}

All measurement was done in triplicate and data were reported as means \pm standard deviation (SD). The analysis of variance and significant differences were tested by one-way ANOVA using SPSS software (version 16.0 for windows, SPSS Inc., Chicago). It was considered that $p \leq 0.05$ was statistically significant.

\section{RESULTS AND DISCUSSIONS}

\section{Antimicrobial activities of lemongrass extract}

Antimicrobial activities of lemongrass extract were evaluated in this study. The data showed that lemongrass extract inhibited the growth of all microorganisms at concentrations $(36 \mu \mathrm{l})$ for fungi species and bacteria species. The data exhibited that bacteria species were more resistant to lemongrass extract than fungi species. In general, the reduction of viable bacteria cells gradually increased according to the increase of the extract concentration, which was added to the growth agar media.

The tabulated results indicated that $P S$. aeruginosa and fragi were sensitive to lemongrass extract than ps. fluorescens, which were utterly inhibited in the presence of $42 \mu \mathrm{g} / \mathrm{mL}$ of extract, while Ps. fluorescens was still viable when the same concentration was added to the growth agar media. From the data, it can also be noticed that Aero. hydrophila was more resistant to lemongrass extract than Aero. caviae and sobria. On the other hand, the results revealed that MIC for Asp. niger and Asp. falvus of lemongrass extract was $(36 \mu \mathrm{l} / \mathrm{mL})$, while MIC for Penicillium spp. was $(30 \mu \mathrm{l} / \mathrm{mL})$ of lemongrass extract (Table 2). The inhibition effect of lemongrass may be due to its bactericidal components such as phenols, flavonoids and essential oil. According to Singh et al. (2011), phenolic compounds and tannins have been found to inhibit pathogenic microorganisms. Ewansiha et al. (2012) mentioned that lemongrass showed antimicrobial activity against Staph. aureus, Salmonella typhi and E. coli. All molds, yeasts, Lactobacillus and most of the Bacillus spp. were sensitive to lemongrass oil.

Antimicrobial tests using the diffusion method showed that lemongrass extract inhibited the growth of Pseudomonas and Aeromonas spp. The data revealed that Aero. hydrophila was more resistant to lemongrass extract than sobria and caviae, which had inhibition zone $27 \pm 0.3,29 \pm 0.1$ and $31 \pm 0.4 \mathrm{~mm}$, respectively (Fig 1). On the contrary, Ps. fragi and aeruginosa were sensitive to lemongrass extract than Ps. fluorescens by inhibition zone $32 \pm 0.3$, $31 \pm 0.1$ and $28 \pm 0.6 \mathrm{~mm}$, respectively (Fig 2). on the other hand, Asp. niger and flavus showed inhibition zone $33 \pm 0.4 \mathrm{~mm}$ while Penicillium spp. were sensitive to lemongrass extract than Asp. spp. as well, Penicillium spp. had inhibition zone $35 \pm 0.1 \mathrm{~mm}$ (Fig $3)$.

\section{Viability of probiotics in frozen yogurt}

Our results showed a slight decrease in the viable counts of $L b$. acidophilus and B. lactis in all treatments during the frozen storage period (30 days). The initial viable cell counts of $L b$. acidophilus and $B$. lactis for all treatments were between $7.97 \pm 0.02-7.60$ \pm 0.07 and $6.91 \pm 0.01-6.25 \pm 0.04 \log \mathrm{CFU} / \mathrm{g}$, respectively (Table 3 ). From the data, it can be observed that counts of Lactobacilli decreased between 0.7 and $1.15 \log \mathrm{CFU} / \mathrm{g}$, depending on probiotic frozen yogurt treatments. Nonetheless, after 30 days of freezing storage, the population of these microorganisms remained above $10^{5} \mathrm{CFU} / \mathrm{g}$ (5.49 $\pm 0.10 \log \mathrm{CFU} / \mathrm{g})$. These results agreed with the minimum level suggested by Samona and Robinson (1994) for probiotic microorganisms in fermented milk products to produce therapeutic benefits. Bifidobacteria showed decreases between 0.76 and $1.36 \log \mathrm{CFU} / \mathrm{g}$ in all treatments. 
Table (2): Minimum inhibitory concentrations (MIC) of lemongrass extract on some Aeromonas spp., Pseudomonas spp. and fungi spp.

\begin{tabular}{llllllllll}
\hline & \multicolumn{7}{c}{ Lemongrass concentration $(\boldsymbol{\mu l})$} \\
\cline { 2 - 9 } Microorganisms & $\mathbf{0}$ & $\mathbf{6}$ & $\mathbf{1 2}$ & $\mathbf{1 8}$ & $\mathbf{2 4}$ & $\mathbf{3 0}$ & $\mathbf{3 6}$ & $\mathbf{4 2}$ & $\mathbf{4 8}$ \\
\cline { 2 - 10 } & & & & & (Inhibition \%) & & \\
\hline Aeromonas hydrophila & 0.0 & 3.61 & 10.81 & 20.27 & 40.82 & 68.95 & 79.62 & 92.14 & 100.0 \\
Aeromonas caviae & 0.0 & 8.13 & 16.83 & 31.16 & 56.88 & 81.13 & 93.18 & 100.0 & - \\
Aeromonas sobria & 0.0 & 6.21 & 12.91 & 28.99 & 53.44 & 76.22 & 91.16 & 100.0 & - \\
Pseudomonas fluorescens & 0.0 & 5.21 & 18.10 & 22.33 & 44.81 & 66.11 & 81.25 & 90.0 & 100.0 \\
Pseudomonas aeruginosa & 0.0 & 8.12 & 24.08 & 28.86 & 51.62 & 84.18 & 95.73 & 100.0 & - \\
Pseudomonas fragi & 0.0 & 6.12 & 18.31 & 28.79 & 50.29 & 79.82 & 93.68 & 100.0 & - \\
Aspergillus niger & 0.0 & 5.29 & 20.83 & 50.17 & 78.81 & 83.1 & 100.0 &
\end{tabular}

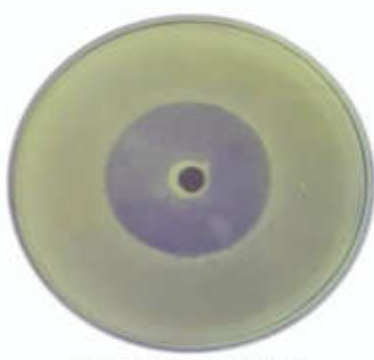

Aeromonas caviae

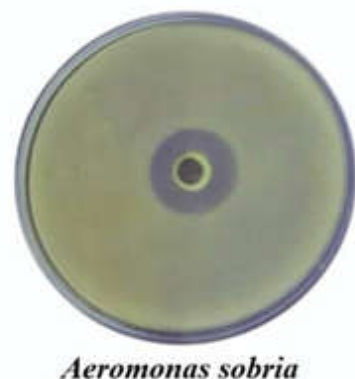

Aeromonas sobria

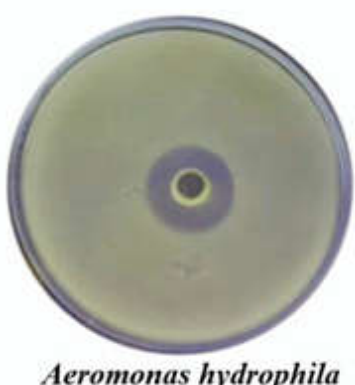

Aeromonas hydrophila

Figure (1): Inhibition zones produced against Aeromonas spp. by using lemongrass extract

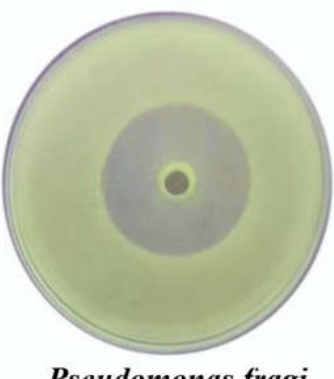

Pseudomonas fragi

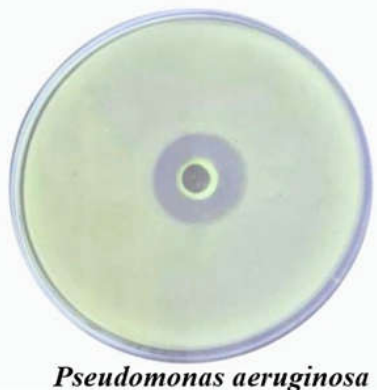

Pseudomonas aeruginosa

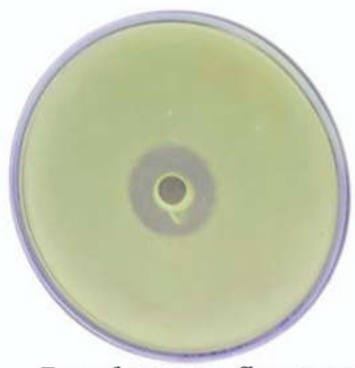

Pseudomonas fluorescens

Figure (2): Inhibition zones produced against Pseudomonas spp. by using lemongrass extract.

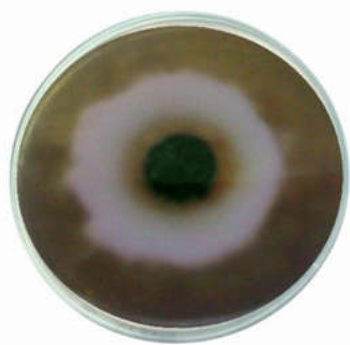

Penicillium ssp.

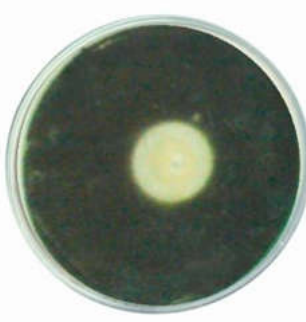

Aspergillus niger

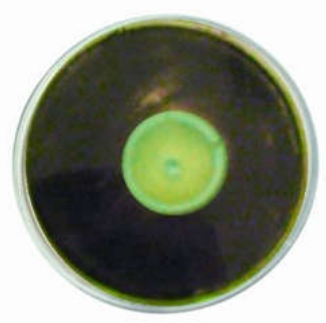

Aspergillus flavus

Figure (3): Inhibition zones produced against Asp. niger, Asp. flavus and Penicillim spp. by using lemongrass extract. 
Table (3): The viability of probiotic bacteria in frozen yogurt fortified with lemongrass (mean \pm S.D)

Probiotic count $(\log \mathrm{CFU} / \mathrm{g})$

\begin{tabular}{|c|c|c|c|c|c|c|c|c|c|c|}
\hline \multirow{3}{*}{$\begin{array}{l}\text { Days of } \\
\text { storage } \\
\text { at }-18^{\circ} \mathrm{C}\end{array}$} & \multirow{2}{*}{\multicolumn{2}{|c|}{ T0 }} & \multirow{2}{*}{\multicolumn{2}{|c|}{ T1 }} & \multirow{2}{*}{\multicolumn{2}{|c|}{ T2 }} & & & & \\
\hline & & & & & & & \multicolumn{2}{|l|}{ T3 } & \multicolumn{2}{|l|}{ T4 } \\
\hline & $\begin{array}{c}\text { Lb. } \\
\text { acidophilus }\end{array}$ & $\begin{array}{c}B . \\
\text { lactis }\end{array}$ & $\begin{array}{c}\text { Lb. } \\
\text { acidophilus }\end{array}$ & $\begin{array}{c}B . \\
\text { lactis }\end{array}$ & $\begin{array}{c}\text { Lb. } \\
\text { acidophilus }\end{array}$ & $\begin{array}{c}B . \\
\text { lactis }\end{array}$ & $\begin{array}{c}\text { Lb. } \\
\text { acidophilus }\end{array}$ & $\begin{array}{c}B . \\
\text { lactis }\end{array}$ & $\begin{array}{c}\text { Lb. } \\
\text { acidophilus }\end{array}$ & $\begin{array}{c}B . \\
\text { lactis }\end{array}$ \\
\hline $\mathbf{0}$ & $\begin{array}{c}7.83 \\
\pm 0.01\end{array}$ & $\begin{array}{c}6.56 \\
\pm 0.12\end{array}$ & $\begin{array}{c}7.97 \\
\pm 0.02\end{array}$ & $\begin{array}{c}6.91 \\
\pm 0.01\end{array}$ & $\begin{array}{c}7.95 \\
\pm 0.04\end{array}$ & $\begin{array}{c}6.90 \\
\pm 0.01\end{array}$ & $\begin{array}{c}7.63 \\
\pm 0.03\end{array}$ & $\begin{array}{c}6.38 \\
\pm 0.06\end{array}$ & $\begin{array}{c}7.60 \\
\pm 0.07\end{array}$ & $\begin{array}{c}6.25 \\
\pm 0.04\end{array}$ \\
\hline 7 & $\begin{array}{c}7.72 \\
\pm 0.09\end{array}$ & $\begin{array}{c}6.56 \\
\pm 0.03\end{array}$ & $\begin{array}{c}7.83 \\
\pm 0.04\end{array}$ & $\begin{array}{c}6.69 \\
\pm 0.04\end{array}$ & $\begin{array}{c}7.80 \\
\pm 0.07\end{array}$ & $\begin{array}{c}6.66 \\
\pm 0.03\end{array}$ & $\begin{array}{c}7.43 \\
\pm 0.10\end{array}$ & $\begin{array}{c}6.35 \\
\pm 0.08\end{array}$ & $\begin{array}{c}7.41 \\
\pm 0.18\end{array}$ & $\begin{array}{c}6.20 \\
\pm 0.05\end{array}$ \\
\hline 15 & $\begin{array}{c}7.33 \\
\pm 0.07\end{array}$ & $\begin{array}{c}5.96 \\
\pm 0.02\end{array}$ & $\begin{array}{c}7.43 \\
\pm 0.04\end{array}$ & $\begin{array}{c}6.49 \\
\pm 0.03\end{array}$ & $\begin{array}{l}7.42 \\
\pm 0.10\end{array}$ & $\begin{array}{c}6.47 \\
\pm 0.02\end{array}$ & $\begin{array}{c}7.31 \\
\pm 0.04\end{array}$ & $\begin{array}{c}5.83 \\
\pm 0.03\end{array}$ & $\begin{array}{c}7.02 \\
\pm 0.05\end{array}$ & $\begin{array}{c}5.82 \\
\pm 0.04\end{array}$ \\
\hline 30 & $\begin{array}{c}6.86 \\
\pm 0.03\end{array}$ & $\begin{array}{c}5.50 \\
\pm 0.09\end{array}$ & $\begin{array}{c}6.96 \\
\pm 0.03\end{array}$ & $\begin{array}{c}5.55 \\
\pm 0.07\end{array}$ & $\begin{array}{c}6.90 \\
\pm 0.03\end{array}$ & $\begin{array}{c}5.65 \\
\pm 0.05\end{array}$ & $\begin{array}{c}6.48 \\
\pm 0.04\end{array}$ & $\begin{array}{c}5.51 \\
\pm 0.07\end{array}$ & $\begin{array}{c}6.55 \\
\pm 0.13\end{array}$ & $\begin{array}{c}5.49 \\
\pm 0.10\end{array}$ \\
\hline
\end{tabular}

T0: Control

T1: yogurt with $0.5 \%$ lemongrass powder

T2: yogurt with $1.0 \%$ lemongrass powder

T3: yogurt with $0.5 \%$ lemongrass extract

T4: yogurt with $1.0 \%$ lemongrass extract

The expected decreasing of viable count due to the adverse effects of freezing condition for the viability of bacteria. A loss of half to one log cycle in viable counts caused by the freezing process (Davidson et al., 2000). Furthermore, this reduction of bacterial counts could be due to acid's ability to enhance the negative effect on bacterial growth.

Treatments 1 and 2 had the lowest decrease of Lactobacilli and Bifidobacteria counts, followed by the control sample. This reduction could be due to lemongrass addition as a powder form that provides conditions that may protect or enhance bacterial growth.

Natural additives were used to control fungal spoilage for clean-label products. In this study, lemongrass was used to control yeast and mold spoilage of frozen yogurt. The average value of molds and yeasts count of different treatments of yogurt was not more than $10^{3} \mathrm{CFU} / \mathrm{g}$ compared to the control sample. (The data is not tabulated). It means that all yogurt treatments were outstanding in hygiene. According to Nyamath and Karthikeyan (2018), lemongrass had antimicrobial activity against gram-positive and gram-negative bacteria, yeasts and molds.

\section{Antioxidant effect of lemongrass powder and extract in frozen yogurt}

TBA test involves the reaction between MDA resulted from lipid oxidation and TBA reagent and formation of pink color. The oxidation of polyunsaturated fatty acids in yogurt leads to the formation of a TBA pink color with maximum absorption at $532 \mathrm{~nm}$ (Semeniuc et al., 2016). Lemongrass had a significant effect $(P \leq 0.05)$ on TBA values in yogurt samples compared with the control sample. During storage, TBA showed a significant increase from $0.9 \mathrm{mg} \mathrm{MDA} / \mathrm{Kg}$ yogurt at zero time to $1.63 \mathrm{mg}$ after 30 days of frozen storage at $-18^{\circ} \mathrm{C} \pm 1$ for the control sample and from $0.8 \mathrm{mg}$ to $1.02,1.00,1.08$ and $1.04 \mathrm{mg} \mathrm{MDA} / \mathrm{Kg}$ yogurt after 30 days of frozen storage for T1, T2, T3 and T4, respectively (Table 4).

This decrease in TBA values in treatments might be due to the presence of bioactive compounds in lemongrass, which have antioxidant effect; the data also revealed a significant difference in the TBA values of different treatments. It can be assumed that the addition of lemongrass (powder or extract) to yogurt caused a reduction of oxidation and aldehydes formation compared to control. There were also significant differences in additive material type (powder or extract) or in lemongrass addition concentrations. The high lemongrass ratio tended to have slightly lower TBA absorbance scores than the low ratio. According to Hartatie et al. (2019), lipid oxidation in broiler meat was reduced by using lemongrass as a natural antioxidant. Lemongrass is used as a medicinal tea with antimicrobial and antioxidant properties (Kieling et al., 2019). Lemongrass contains essential oil and phenolic compounds known to have antioxidant activity (Anggraeni et al., 2018). 
Table (4): Effect of lemongrass on thiobarbituric acid value (mg MDA/kg) of frozen yogurt during storage at $-18^{\circ} \mathrm{C} \pm 1$ $($ Mean \pm SD)

\begin{tabular}{|c|c|c|c|c|c|}
\hline \multirow{2}{*}{ Treatments } & \multicolumn{5}{|c|}{ Storage time (days) } \\
\hline & $\mathbf{0}$ & 5 & 15 & 20 & 30 \\
\hline $\mathbf{T}_{\mathbf{0}}$ & $0.91^{\mathrm{a}} \pm 0.002$ & $1.01^{\mathrm{a}} \pm 0.002$ & $1.21^{\mathrm{a}} \pm 0.071$ & $1.39^{\mathrm{a}} \pm 0.719$ & $1.63^{\mathrm{a}} \pm 0.191$ \\
\hline $\mathbf{T}_{1}$ & $0.82^{b} \pm 0.121$ & $0.85^{\mathrm{c}} \pm 0.225$ & $0.91^{b} \pm 0.003$ & $0.98^{\mathrm{c}} \pm 0.211$ & $1.02^{\mathrm{c}} \pm 0.138$ \\
\hline $\mathbf{T}_{2}$ & $0.80^{b} \pm 0.331$ & $0.81^{\mathrm{d}} \pm 0.142$ & $0.88^{\mathrm{c}} \pm 0.008$ & $0.90^{\mathrm{b}} \pm 0.254$ & $1.00^{c} \pm 0.145$ \\
\hline $\mathbf{T}_{\mathbf{3}}$ & $0.82^{\mathrm{b}} \pm 0.421$ & $0.89^{b} \pm 0.115$ & $0.93^{b} \pm 0.113$ & $0.99^{\mathrm{b}} \pm 0.617$ & $1.08^{\mathrm{b}} \pm 0.111$ \\
\hline $\mathbf{T}_{4}$ & $0.81^{\mathrm{b}} \pm 0.008$ & $0.82^{\mathrm{d}} \pm 0.161$ & $0.89^{c} \pm 0.004$ & $0.92^{\mathrm{b}} \pm 0.476$ & $1.01^{\mathrm{c}} \pm 0.002$ \\
\hline
\end{tabular}

Means within the same column marked with different letters are significantly different are $(\mathrm{P}<0.05)$.

T0: Control

T1: yogurt with $0.5 \%$ lemongrass powder $\quad$ T3: yogurt with $0.5 \%$ lemongrass extract

T2: yogurt with $1.0 \%$ lemongrass powder $\quad$ T4: yogurt with $1.0 \%$ lemongrass extract

\section{Effect of lemongrass powder and extract on color parameters of frozen yogurt}

Color is one of the most important sensory attributes as it helps us to reject or accept food. Lemongrass effect on frozen yogurt's color parameters was studied during storage at $-18^{\circ} \mathrm{C} \pm 1$ for 30 days. Table (5) showed that lightness $L^{*}$ and yellowness $b^{*}$ were increased by increasing storage time up to 30 days. On the contrary, $a^{*}$ value decreasing from -2.15 at zero time to -2.54 after 30 days of frozen storage. Color change may be referred to the chemical changes during storage (AbdEl Fattah et al., 2010). Also, Wallace and Giusti (2008) reported that powders and extracts of fruits and vegetables could be a functional component in food. In our study, the addition of lemongrass powder or extract to yogurt produced an attractive, stable color, stable quality product and eliminating the need for industrial colorant extraction.

Table (5): Effect of lemongrass on color parameters of frozen yogurt during storage at $-18^{\circ} \mathrm{C} \pm 1$ (Mean \pm S.D).

\begin{tabular}{|c|c|c|c|c|c|c|}
\hline \multirow{2}{*}{ Treatment } & $L^{*}$ & $b^{*}$ & $a^{*}$ & $L^{*}$ & $b^{*}$ & $a^{*}$ \\
\hline & \multicolumn{3}{|c|}{ At zero time } & \multicolumn{3}{|c|}{ After 30 days of storage } \\
\hline T0 & $91.82 \pm 0.11$ & $10.78 \pm 0.014$ & $-2.15 \pm 0.111$ & $92.11 \pm 0.102$ & $11.82 \pm 0.111$ & $-2.54 \pm 0.113$ \\
\hline T1 & $91.31 \pm 0.002$ & $10.61 \pm 0.009$ & $-2.14 \pm 0.321$ & $92.69 \pm 0.007$ & $11.73 \pm 0.006$ & $-2.31 \pm 0.111$ \\
\hline $\mathbf{T} 2$ & $90.98 \pm 0.008$ & $10.63 \pm 0.021$ & $-2.11 \pm 0.235$ & $92.71 \pm 0.025$ & $11.69 \pm 0.013$ & $-2.29 \pm 0.231$ \\
\hline T3 & $91.73 \pm 0.031$ & $10.79 \pm 0.031$ & $-2.13 \pm 0.142$ & $92.70 \pm 0.002$ & $11.74 \pm 0.152$ & $-2.34 \pm 0.007$ \\
\hline T4 & $91.25 \pm 0.001$ & $10.62 \pm 0.052$ & $-2.11 \pm 0.135$ & $92.76 \pm 0.031$ & $11.71 \pm 0.009$ & $-2.25 \pm 0.121$ \\
\hline
\end{tabular}

T0: Control

T1: yogurt with $0.5 \%$ lemongrass powder

T2: yogurt with $1.0 \%$ lemongrass powder

T3: yogurt with $0.5 \%$ lemongrass extract

T4: yogurt with $1.0 \%$ lemongrass extract

\section{Effect of lemongrass powder or extract on sensory characteristics of frozen yogurt}

Sensory evaluation showed that frozen yogurt fortified with lemongrass powder $0.5 \%$ had a good body, texture, flavor and quality characteristics with higher antioxidant effect (TBA values $1.02 \mathrm{mg}$ $\mathrm{MAD} / \mathrm{kg}$ ) compared with frozen yogurt fortified with lemongrass powder $1 \%$ and lemongrass extract $0.5-1 \%$.
Although T1 had the highest sensory mean scores, all lemongrass frozen yogurt treatments showed higher flavor scores with accepted mild acid taste than the control sample (Table 6). Frozen yogurt was commercially evaluated to be the lowest-acid product. Moreover, lemongrass can also add a pleasant light, lemony flavor to foods (Abdelazez et al., 2017). 
Table (6): Effect of lemongrass on sensory characteristics of frozen yogurt during storage at $-18^{\circ} \mathrm{C} \pm 1$ (Mean \pm S.D).

\begin{tabular}{ccccc}
\hline $\begin{array}{c}\text { Days } \\
\text { Treatments }\end{array}$ & Zero & $\mathbf{7}$ & $\mathbf{1 5}$ & $\mathbf{3 0}$ \\
\hline Control & $72.0^{\mathrm{d}} \pm 1.000$ & $71.6^{\mathrm{d}} \pm 0.570$ & $70.0^{\mathrm{d}} \pm 1.000$ & $69.7^{\mathrm{d}} \pm 1.520$ \\
$\mathbf{T}_{\mathbf{1}}$ & $95.6^{\mathrm{a}} \pm 1.150$ & $95.0^{\mathrm{a}} \pm 0.001$ & $93.0^{\mathrm{a}} \pm 1.732$ & $92.3^{\mathrm{a}} \pm 1.520$ \\
$\mathbf{T}_{\mathbf{2}}$ & $95.0^{\mathrm{a}} \pm 1.130$ & $93.3^{\mathrm{a}} \pm 1.520$ & $92.0^{\mathrm{a}} \pm 1.000$ & $89.7^{\mathrm{a}} \pm 0.570$ \\
$\mathbf{T}_{\mathbf{3}}$ & $89.3^{\mathrm{b}} \pm 0.577$ & $86.7^{\mathrm{b}} \pm 0.570$ & $85.3^{\mathrm{b}} \pm 3.210$ & $84.3^{\mathrm{b}} \pm 0.570$ \\
$\mathbf{T}_{\mathbf{4}}$ & $82.7^{\mathrm{c}} \pm 1.527$ & $81.3^{\mathrm{c}} \pm 0.570$ & $80.0^{\mathrm{c}} \pm 0.001$ & $78.3^{\mathrm{c}} \pm 1.150$ \\
\hline
\end{tabular}

Means with the same column with different superscript $(\mathrm{a}, \mathrm{b}, \mathrm{c} \ldots)$ are not significantly different $(p<0.05)$

T0: Control

T1: yogurt with $0.5 \%$ lemongrass powder

T2: yogurt with $1.0 \%$ lemongrass powder

T3: yogurt with $0.5 \%$ lemongrass extract

T4: yogurt with $1.0 \%$ lemongrass extract

\section{CONCLUSION}

Many studies have focused on probiotics and prebiotics and their health effects. Probiotics and lemongrass as dietary fiber (prebiotics) are well known for their beneficial health effects and source of functional foods. In conclusion, the addition of the powder or extract of lemongrass to frozen yogurt improved the viability of probiotic and quality characteristics of frozen yogurt.

\section{Authors' contributions}

Eldeeb, G.S.S. was involved in chemical and microbial analysis, manuscript writing, correcting and editing. Mosilhey, S.M. was involved in the preparing for the implementation, calculating and manuscript writing. Abouelnaga, M. was involved in processing, data tabulating and manuscript writing. All authors read and approved the final manuscript.

\section{REFERENCES}

Abd-El Fattah, S. M., A. Y. Hassan, H. M. Bayoum and H. A. Eissa (2010). The use of lemongrass extracts as antimicrobial and food additive potential in yoghurt. J. Am. Sci, 6: 582-594. 10.13140/RG.2.1.1899.2729

Abdelazez, A., Z. Muhammad, Q. X. Zhang, Z. T. Zhu, H. Abdelmotaal, R. Sami and X. C. Meng (2017). Production of a functional frozen yogurt fortified with Bifidobacterium spp. BioMed Research International, 2017. https://doi.org/10.1155/2017/6438528

Adeneye, A. A. and E. O. Agbaje (2007). Hypoglycemic and hypolipidemic effects of fresh leaf aqueous extract of Cymbopogon citratus Stapf. in rats. Journal of Ethnopharmacology, 112(3): $\quad$ 440-444. https://doi.org/10.1016/j.jep.2007.03.034

Anggraeni, N. I., I. W. Hidayat, S. D. Rachman and Ersanda. (2018, February). Bioactivity of essential oil from lemongrass (Cymbopogon citrates Stapf) as antioxidant agent. In AIP
Conference Proceedings, 1927(1): 030007. AIP Publishing

LLC. https://doi.org/10.1063/1.5021200

AOAC (2012). Official Methods of Analysis of the Association of Official Analytical Chemistry (A.O.A.C.) International, $19^{\text {th }}$ ed., Gaithersburg, Maryland, USA.

Brothers, A. and R. Wyatt (2000). The Antifungal Activity of Natamycin toward Molds Isolated from Commercially Manufactured Poultry Feed. Avian Diseases, 44(3): 490-497. https://doi.org/10.2307/1593087

Davidson, R. H., S. E. Duncan, C. R. Hackney, W. N. Eigel and J. W. Boling (2000). Probiotic culture survival and implications in fermented frozen yogurt characteristics. Journal of Dairy Science, 83(4): 666-673. https://doi.org/10.3168/jds.S00220302(00)74927-7

De Silva, B. C. J., W. G. Jung, S. Hossain, S. H. M. P. Wimalasena, H. N. K. S. Pathirana and G. J. Heo (2017). Antimicrobial property of lemongrass (Cymbopogon citratus) oil against pathogenic bacteria isolated from pet turtles. Laboratory Animal Research, 33(2): 84-91. https://doi.org/10.5625/lar.2017.33.2.84

Ewansiha, J. U., S. A. Garba, J. D. Mawak and O. A. Oyewole (2012). Antimicrobial Activity of Cymbopogon citratus (Lemon Grass) and It's Phytochemical Properties. Frontiers in Science, 2(6): $\quad$ 214-220. DOI: $10.5923 /$ j.fs.20120206.14

Favaro-Trindade, C. S., S. Bernardi, R. B. Bodini, J. C. De Carvalho Balieiro and E. De Almeida (2006). Sensory acceptability and stability of probiotic microorganisms and vitamin $\mathrm{C}$ in fermented acerola (Malpighia emarginata DC.) ice cream. Journal of Food Science, 71(6): S492S495. https://doi.org/10.1111/j.17503841.2006.00100.x

Figueirinha, A., A. Paranhos, J. J. Pérez-Alonso, C. 
Santos-Buelga and M. T. Batista (2008). Cymbopogon citratus leaves: Characterization of flavonoids by HPLC-PDA-ESI/MS/MS and an approach to their potential as a source of bioactive polyphenols. Food Chemistry, 110(3): 718-728. https://doi.org/10.1016/j.foodchem.2008.02.04 5

Hartatie, E. S., I. Prihartini, W. Widodo and A. Wahyudi (2019). Bioactive Compounds of Lemongrass (Cymbopogon citratus) essential oil from different parts of the plant and distillation methods as natural antioxidant in broiler meat. In $I O P$ Conference Series: Materials Science and Engineering, 532(1): 012018. https://doi.org/10.1088/1757899X/532/1/012018

Jayamanne, V. S. and M. R. Adams (2006). Determination of survival, identity and stress resistance of probiotic bifidobacteria in bioyoghurts. Letters in Applied Microbiology, 42(3): 189-194. https://doi.org/10.1111/j.1472765X.2006.01843.x

Kieling, D. D., G. V. Barbosa-Cánovas and S. H. Prudencio (2019). Effects of high-pressure processing on the physicochemical and microbiological parameters, bioactive compounds, and antioxidant activity of a lemongrass-lime mixed beverage. Journal of Food science and Technology, 56(1): 409419. https://doi.org/10.1007/s13197-0183502-6

Li, C. C., H. F. Yu, C. H. Chang, Y. T. Liu and H. T. Yao (2018). Effects of lemongrass oil and citral on hepatic drug-metabolizing enzymes, oxidative stress, and acetaminophen toxicity in rats. Journal of Food and Drug Analysis, 26(1): $\quad$ 432-438. https://doi.org/10.1016/j.jfda.2017.01.008

Magarinos, H., S. Selaive, M. Costa, M. Flores and O. Pizarro (2007). Viability of probiotic microorganisms (Lactobacillus acidophilus la-5 and Bifidobacterium animalis subsp. Lactis bb-12) in ice cream. International Journal of Dairy Technology, 60(2):

$128-$ $134 . \quad$ https://doi.org/10.1111/j.1471 0307.2007.00307.x

Majewska, E., M. Kozlowska, E. GruszczynskaSekowska, D. Kowalska and K. Tarnowska (2019). Lemongrass (Cymbopogon citratus) essential oil: extraction, composition, bioactivity and uses for food preservation-a review. Polish Journal of Food and Nutrition Sciences, 69(4): 327-341. DOI: https://doi.org/10.31883/pjfns/113152

Marshall, R.T. and W. S. Arbuckle (1996). Ice Cream. $5^{\text {th }}$ Edition, Chapman \& Hall, New York, USA. https://dx.doi.org/10.1007/978-1-46130477-7

Nyamath, S. and B. Karthikeyan (2018). In vitro antibacterial activity of lemongrass (Cymbopogon citratus) leaves extract by agar well method. Journal of Pharmacognosy and Phytochemistry, 7(3), 1185-1188.

Pearson's (1981). Chemical Analysis of Food. Edinburgh London Melbourne and New York.

Piddock, L. J. (1990). Techniques used for the determination of antimicrobial resistance and sensitivity in bacteria. Journal of Applied Bacteriology, 68(4): 307-318. doi: 10.1111/j.1365-2672.1990.tb02880.x.

Salama, F. M. M. (2004). The use of some natural sweeteners in ice cream manufacture. Egyptian Journal of Dairy Science, 32: 355 366.

Samona, A. and R. K. Robinson (1994). Effect of yogurt cultures on the survival of bifidobacteria in fermented milks. International Journal of Dairy Technology, 47(2): $\quad 58-60$. https://doi.org/10.1111/j.14710307.1994.tb01273.x

Semeniuc, C. A., M. Mandrioli, M. T. RodriguezEstrada, S. Muste and G. Lercker (2016). Thiobarbituric acid reactive substances in flavored phytosterol-enriched drinking yogurts during storage: Formation and matrix interferences. European Food Research and Technology, 242(3): 431-439. DOI $10.1007 / \mathrm{s} 00217-015-2554-3$

Singh, B. R., V. Singh, R. K. Singh and N. Ebibeni (2011). Antimicrobial activity of lemongrass (Cymbopogon citratus) oil against microbes of environmental, clinical and food origin. Int Res J Pharm Pharmacol, 1(9): 228-236.

Wallace, T. C. and M. M. Giusti (2008). Determination of color, pigment, and phenolic stability in yogurt systems colored with nonacylated anthocyanins from Berberis boliviana L. as compared to other natural/synthetic colorants. Journal of Food Science, 73(4): C241-C248. https://doi.org/10.1111/j.17503841.2008.00706.x. 


\section{تحسين خواص الجودة للزبادى المجمد بواسطة تلعيمه بحشيشة الليمون كداعم حيوي

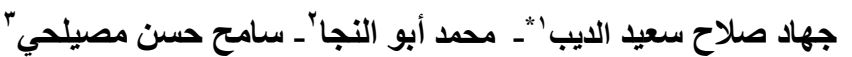

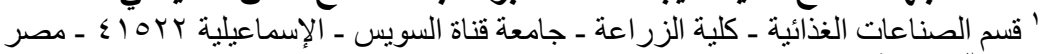

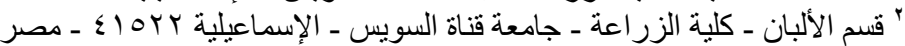 \\ " ق قسم علوم وتكنولوجيا الأغذية والألبان ـ كلية العلوم الزر اعية البيئية ـ جامعة العريش ـ محافظة شمال سيناء}

يهدف هذا البحث إلى در اسة تأثير إضافة حثيشة الليمون كمضاد للميكروبات وكمعزز ومدعم لنمو بكتريا البروبيوتيك في منتج

[Lactobacillus acidophilus (LA- الزبادي المجمد. تم تصنيع الزبادي بسلاتلات Streptococcus thermophiles [5), Bifidobacterium lactis (BB-12)]

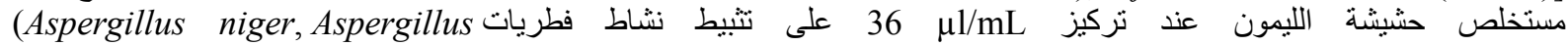
(Pseudomonas fluorescens, aeruginosa fragi و وند تركيز 48 وامت بتثبيط بكتريا and Aeromonas hydrophila, caviae, sobria)

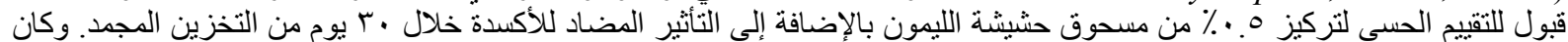

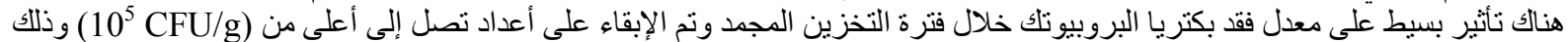
مقارنة بالعينة الكنترول. 